\title{
Human resources for health density and its associations with child and maternal mortality in the Islamic Republic of Iran
}

Zahra Madadi, ${ }^{1}$ Farhad Pishgar, ${ }^{1}$ Erfan Ghasemi, ${ }^{1}$ Alireza Khajavi, ${ }^{1,3}$ Sahar Moghaddam ${ }^{1,2}$ and Farshad Farzadfar ${ }^{1}$

${ }^{1}$ Non-Communicable Diseases Research Center, Endocrinology and Metabolism Population Sciences Institute, Tehran University of Medical Sciences, Tehran, Islamic Republic of Iran (Correspondence to: F. Farzadfar: F-Farzadfar@tums.ac.ir). ${ }^{2}$ Endocrinology and Metabolism Research Center, Endocrinology and Metabolism Clinical Sciences Institute, Tehran University of Medical Sciences, Tehran, Islamic Republic of Iran. ${ }^{3}$ Department of Biostatistics, Faculty of Paramedical Sciences, Shahid Beheshti University of Medical Sciences, Tehran, Islamic Republic of Iran.

\begin{abstract}
Background: The Family Physician and Social Protection Scheme for Iranian rural inhabitants was launched in June 2005 to improve physician density. To our knowledge, a comprehensive study of the impact of the Scheme on mortality-related health indicators has not been conducted.

Aims: To investigate the effects of health workforce density on maternal, neonatal, infant and under-5 mortality rates in rural areas of the Islamic Republic of Iran between 2005 and 2011.

Methods: We built mixed-effects Poisson regression models including mortality measures as response variables and physician and behvarz (community-based health worker) densities as independent variables, using data from the Iranian Vital Horoscope tool, annual Households Income and Expenditure Survey, and DTARH software. We also included population sizes, age of inhabitants, rate of urbanization, years of schooling, and wealth index in each district, as well as effect of time, as covariates.

Results: Physician density was significantly associated with child mortality rates $(1.5 \%, 1.1 \%$ and $63.5 \%$ decrease in neonatal, under- 5 and maternal mortality with a 1-unit increase in physician density per 1000 individuals). In the model built for infant mortality rate, physician density and behvarz densities were not significantly associated with this measure.

Conclusions: Improving the distribution of family physicians was associated with lower child and maternal mortality. Improvements in behvarz densities were not associated with decrements in these rates, which probably calls for improvement in access to more professional health services and facilities.
\end{abstract}

Keywords: child mortality, family physicians, infant mortality, Islamic Republic of Iran, maternal mortality.

Citation: Madadi Z; Pishgar F; Ghasemi E; Khajavi A; Moghaddam S; Farzadfar F. Human resources for health density and its associations with child and maternal mortality in the Islamic Republic of Iran. East Mediterr Health J. 2021;27(1):16-22. https://doi.org/10.26719/2021.27.1.16

Received: 08/01/19; accepted: 16/01/20

Copyright (C) World Health Organization (WHO) 2021. Open Access. Some rights reserved. This work is available under the CC BY-NC-SA 3.0 IGO license (https://creativecommons.org/licenses/by-nc-sa/3.o/igo).

\section{Introduction}

In 2015, the Millennium Development Goals (MDGs) were replaced by the more detailed Sustainable Development Goals (SDGs) to create a framework for ending poverty, protecting the planet, and ensuring prosperity for all by 2030. The third goal of the SDGs addresses health-related obstacles in the path to sustainable development, and calls for improving maternal and child mortality rates, as well as universal health coverage (UHC) and access to healthcare services, such as vaccination and family planning $(1,2)$. UHC is defined as the availability of quality essential primary health services to all people, which necessitates promoting insurance coverage, increasing the extent of primary health services covered by insurance, and improving inequalities in the availability of these services (3). The provision of access to a trained and motivated health workforce, including community-based health workers (known as behvarzes in the Islamic Republic of Iran), midwives, and family physicians (FPs), is known a critical step in improving UHC in lowand high-income societies (4).
In 2004, the Joint Learning Initiative proposed that training a motivated health workforce, improving work environments for these workers, fair distribution of health human resources, and implementing health strategies designed to meet the health needs of each society lie at the centre of shaping sustainable health systems in all countries (5). Several studies have shown the roles of human resources in improving health outcomes, ranging from prevention and management of noncommunicable diseases (NCDs) to lowering maternal, neonatal and under-5-year mortality rates $(6,7)$.

In rural regions of the Islamic Republic of Iran, the smallest health facility, which is part of the primary healthcare network, is known as the health house. Each health house is staffed by at least 1 community-based health worker (behvarz), who is selected form residents of the same village and is trained for 2 years. Health houses provide primary health services, including vaccinations, prenatal and postnatal primary healthcare, growth monitoring, and management of common infections. Patients with more severe conditions that cannot be managed in health houses are referred to rural health 
centres to be visited by rural FPs (6).

The Family Physician and Social Protection Scheme was launched in June 2005 for rural inhabitants to improve physician density in areas covered by the scheme (8). We conducted the present nationally representative study to investigate the effects of health workforce density, including FPs and behvarzes, on maternal mortality rate (MMR), neonatal mortality rate (NMR), infant mortality rate (IMR), and under-5-year mortality rate (U5MR) in rural areas of the Islamic Republic of Iran between 2005 and 2011.

\section{Methods}

\section{Data collection}

Data used in this cross-sectional study were collected from multiple sources. Annual numbers of deaths, including MMR (number of pregnancy-related maternal deaths per 100 ooo live births), NMR (number of neonatal deaths per 1000 live births), IMR (number of infant deaths per 1000 live births) and U5MR (number of under-5-year deaths per 1000 live births), in each district, as well as data on live births were collected from the Iranian Vital Horoscope tool. This tool was designed to record vital events such as births, deaths and family planning activities in rural areas. It consists of a paper sheet that is kept pinned to the wall at the health house. These data were used to calculate MMR, NMR, IMR and U5MR.

Data on numbers of inhabitants, residents' mean age, rate of urbanization, average years of schooling, and wealth status in each district were collected from surveys and census data, including the annual Households Income and Expenditure Survey (HIES), which were performed by the Statistical Center of Iran. The Wealth Index (WI) is a reduced-dimension measure of a household's cumulative living standards. We used principal component analysis (PCA) and created a WI based on the national HIES. PCA was performed on 14 assets including: home area; number of rooms; type of materials used for home construction; type of fuel used for home heating; ownership of washing machines, freezers, vacuum cleaners, personal computers, mobile phones, telephones and cars; and kitchens, bathrooms and access to mains gas. The values ranged between -4 and +4 . After calculating wealth at household level, it was averaged at district level, and the exact values were used in the analyses.

Regional data on years of schooling were unified using the recommended International Standard Classification of Education 1976. The numbers of FPs and behvarzes in each district were gathered from the DTARH software (used in primary healthcare system surveys in the Islamic Republic of Iran). We calculated regional FP and behvarz densities (number per 1000 inhabitants of each area).

\section{Ethical approval}

This study was a reanalysis of the available data and was approved by the Ethics Committee of Tehran University of Medical Sciences.

\section{Statistical analysis}

We built 4 mixed-effects Poisson regression models using the response variables MMR, NMR, IMR and U5MR. We included FP and Behvarz densities as our independent variables. We also included natural logarithm of population size, mean age of inhabitants, rate of urbanization, average years of schooling, and WI in each district, in addition to the effect of time as covariates. The general form of the mixed-effects Poisson regression models was as follows:

$\log \left(Y_{i}\right)=\alpha+\beta_{1} P D+\beta_{2} B D+\beta_{3} M A+\beta_{4} Y S+\beta_{5} W I+\beta_{6} U R+\beta_{7} T I M E+\beta_{7} \log P O P+b_{0 i}$ $+\varepsilon_{i j}$

$\varepsilon_{i j} N\left(0, \sigma^{2}\right)$

$b_{0 i} N\left(0, \sigma_{b 0}^{2}\right)$

Where Y, PD, BD, MA, YS, WI, UR, TIME and log_POP represent our response variables: physician density, behvarz density, regional mean age of inhabitants, regional years of schooling, WI, urbanization rate, years and logarithm of population size in each area, respectively. $b_{0 i}$ and $\varepsilon_{i j}$ Are the random intercept and error terms, respectively, which were independent.

The analyses were carried out using SAS version 9.2 (SAS Institute, Cary, NC, USA), and maps were prepared using the open source $\mathrm{R}$ software, version 3.1.2, and the 'maptools' and 'SDMTools' (Species Distribution Modeling Tools) packages. $P<0.05$ was assumed to be statistically significant.

\section{Results}

MMR, NMR, IMR and U5MR in the Islamic Republic of Iran decreased between 2005 and 2011 (Table 1), and almost in all rural districts over the years of the study (Figure 1). However, inequalities in FP and behvarz densities in these areas were evident, and both of these measures were lowest in the central parts of the country between 2005 and 2011 (Figure 2).

Upon investigating the associations between the covariates and NMR in rural areas, physician density, WI, population size, and mean age of inhabitants were significantly associated with NMR (Table 2). The models showed that a 1-unit increase in FP per 1000 individuals resulted in a $1.5 \%$ decrease in NMR per 1000 live births. However, behvarz density failed to show such associations with NMR. Our analysis of the associations between covariates and IMR showed that WI, population size, and mean age of inhabitants were significantly associated with IMR. However, FP and behvarz densities were not significantly associated with IMR. Our analysis of the association between covariates and U5MR showed that FP density, WI, mean age of inhabitants, urbanization, and population size were significantly associated with U5MR. A 1-unit increase in physician density per 1000 individuals was evaluated to cause a $1.1 \%$ decrease in 


\begin{tabular}{lcc}
\hline Table $\mathbf{1}$ Maternal and child mortality rates in the Islamic Republic of Iran $\mathbf{2 0 0 5}-\mathbf{2 0 1 1}$ & $\mathbf{2 0 1 1}$ \\
Mortality rate & $\mathbf{2 0 0 5}$ & 10.45 \\
Neonatal mortality rate per 1000 live births & 14.66 & $(9.87-11.02)$ \\
& $(13.98-15.34)$ & 15.21 \\
Infant mortality rate per 1000 live births & 20.48 & $(14.41-16.01)$ \\
& $(19.62-21.34)$ & 18.65 \\
Under-5-year mortality rate per 1000 live births & 24.44 & $(17.70-19.60)$ \\
Maternal mortality rate per 1000 live births & $(23.48-25.39)$ & 0.26 \\
& 0.29 & $(0.19-0.32)$ \\
\hline
\end{tabular}

The data are presented with $95 \%$ confidence intervals.

U5MR per 1000 live births. However, the association with behvarz density was not significant. In the model built for assessing the effects of the covariates on MMR, physician density, population size, and mean age of inhabitants were significantly associated with MMR. A 1 -unit increase in physician density per 1000 individuals was evaluated to cause a $63.5 \%$ decrease in $U_{5} M R$ per 1000 live births.

\section{Discussion}

An increase in FP density was significantly associated with decrements in NMR, U5MR and MMR but there was no significant association between FP density and IMR. The data failed to show any significant association between behvarz density and child mortality rates. The data also showed the effects of several socioeconomic variables, including average wealth status and size of the population, on child and maternal mortality.
The effects of health workforce density on health measures have been studied thoroughly in other countries. In a study from Brazil, Sousa et al. showed that an increase of 1 nurse professional and 1 physician per 1000 individuals reduced NMR by $3.8 \%$ and $2.3 \%$, respectively (9). Fernandes et al. studied the determinants of child mortality in Mozambique and observed that the overall health workforce density and the density of specialized nurses for child and maternal care were strongly associated with NMR. However, their findings did not support the contributing role of improving physician density in decreasing infant mortality (10). In contrast, in a cross-country study, Anand and Bärnighausen did show significant associations between physician density and infant mortality (11). These results show that improving accessibility to specialized child and maternal care, such as services provided by physicians and nurse professionals, is more effective in

Figure 1 Child mortality rates in rural areas of the Islamic Republic of Iran in 2011. Neonatal (A), infant (B), and under-5-year (C) mortality rates are shown in these maps using 5 colours, corresponding to quintiles of values
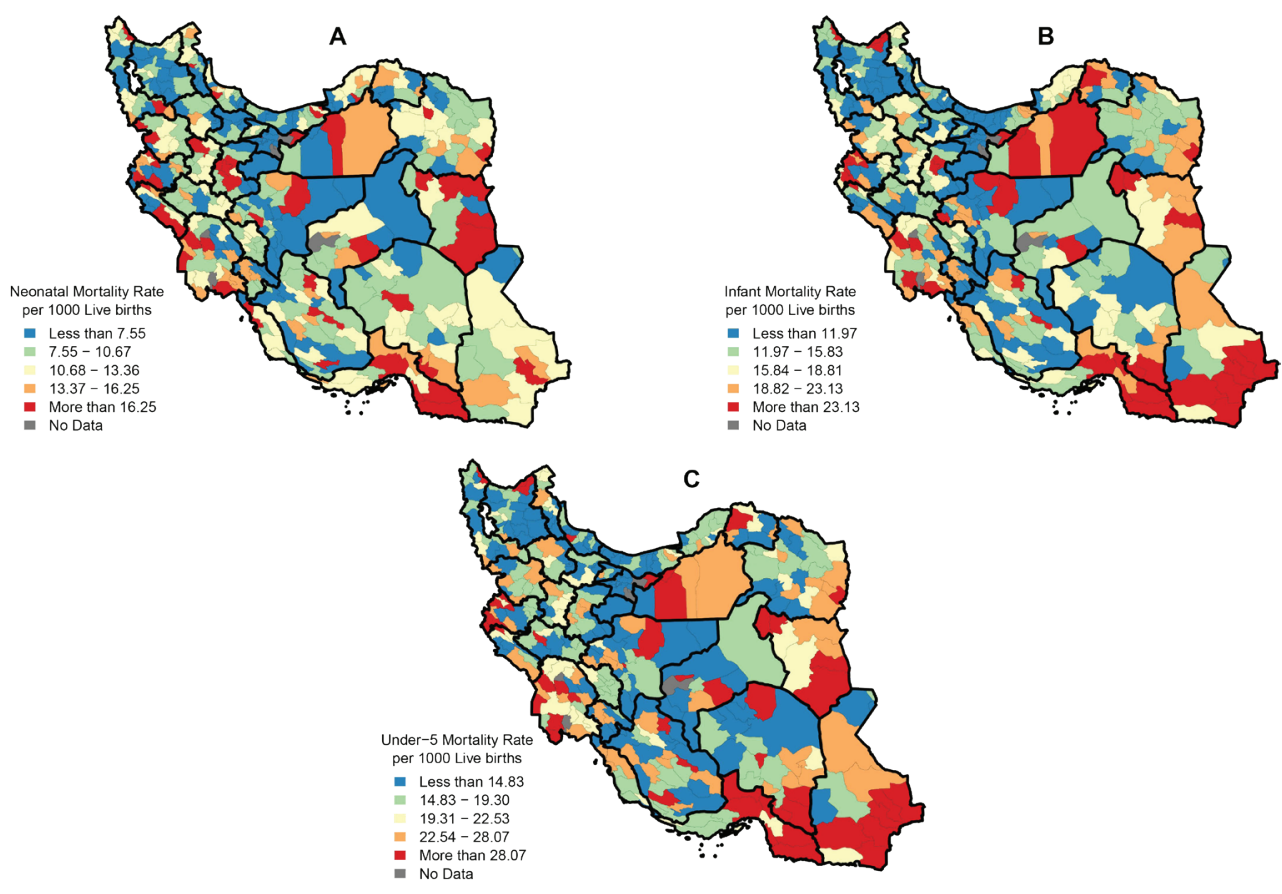
Figure 2 Health workforce density in rural areas of the Islamic Republic of Iran in 2011. Density of family physicians (A) and behvarzes (B) are shown in these maps using 5 colours, corresponding to quintiles of values

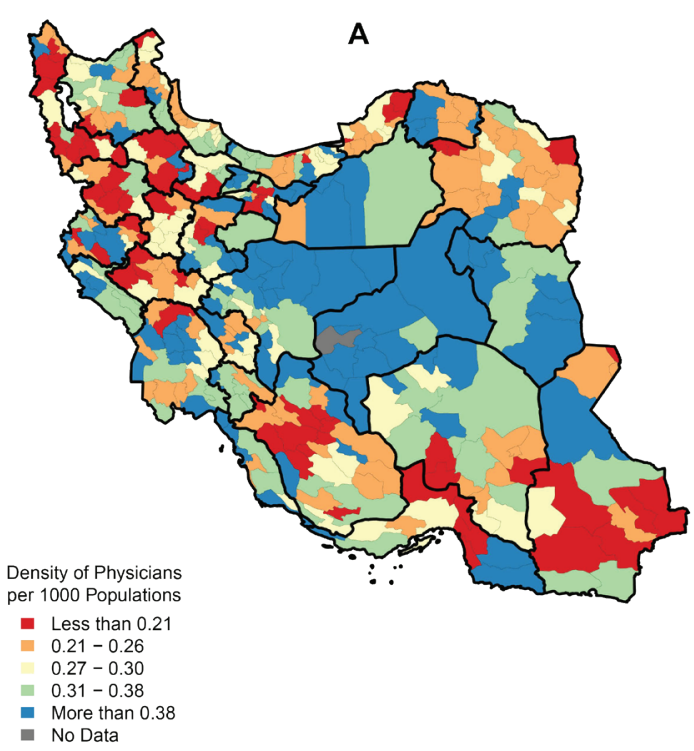

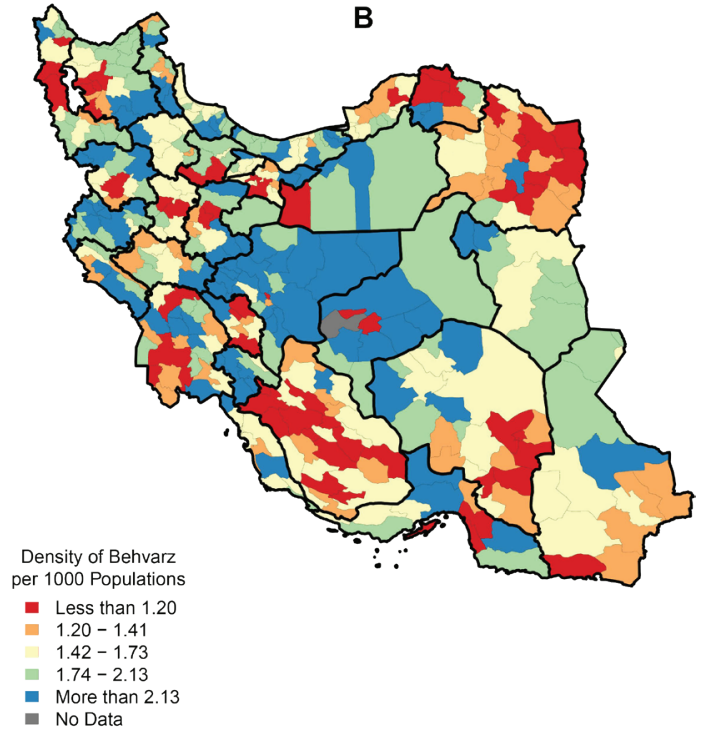

child mortality rates. Several studies have indicated the impact of economic status on child mortality rates (16, 17). Naderimagham et al. conducted a study to evaluate the effects of the FP programme and social factors on mortality rates in the Islamic Republic of Iran from 1995 to 2011 using time-series analysis, and found that residents' wealth status was significantly associated with reductions in child mortality rates (16). Moreover, a National Family Health Survey in India showed that $\geq 9$ years of school education was associated with decreases in child mortality (17).

In addition to the factors in the present study, other variables have been shown to affect mortality rates, such as: breastfeeding promotion, delivery by trained individuals, kangaroo mother care, regular prenatal care, providing supplements for pregnant women, and implementing clinical practice guidelines at all levels of health care $(13,16)$.

This is believed to be the first study to evaluate the effects of health workforce density on infant, child and maternal mortality rates at a national level in the Islamic Republic of Iran. However, our study had several limitations. First, we did not have data on causes of death among children. Hence, our findings cannot be confirmed by reviewing the question of whether the reported decreases in child mortality were due to causes that could be managed by FPs. Second, we had to exclude urban areas from the study, since the Family Physician and Social Protection Scheme was launched only in rural areas. As a result, our findings cannot be generalized to urban areas, where decreasing mortality measures perhaps require a more complex approach. Third, we did not have access to data on distribution of midwives. Earlier reports have shown that maternal mortality decreases with improvement in access to health professionals with midwifery skills $(18,19)$. However, the unavailability of this fing (through WI) and mortality rates. Improved financial status significantly contributed to decreases in 


\begin{tabular}{|c|c|c|c|c|c|c|c|c|}
\hline \multirow[t]{2}{*}{ Variable } & \multicolumn{2}{|c|}{$\begin{array}{c}\text { NMR per } 1000 \\
\text { live births } \\
\text { (No. of observations } \\
\text { 2199) }\end{array}$} & \multicolumn{2}{|c|}{$\begin{array}{c}\text { IMR per } 1000 \\
\text { live births } \\
\text { (No. of observations } \\
\text { 2199) }\end{array}$} & \multicolumn{2}{|c|}{$\begin{array}{c}\text { U5MR per } \\
1000 \text { live births } \\
\text { (No. of observations } \\
\text { 2199) }\end{array}$} & \multicolumn{2}{|c|}{$\begin{array}{c}\text { MMR per } \\
100000 \text { live births } \\
\text { (No. of observations } \\
\text { 2169) }\end{array}$} \\
\hline & b & $\mathbf{P}$ & b & $\mathbf{P}$ & b & $\mathbf{P}$ & & $\boldsymbol{P}$ \\
\hline $\begin{array}{l}\text { Physician density per } 1000 \\
\text { individuals }\end{array}$ & $\begin{array}{c}-0.01482 \\
(-0.02,-0.001)\end{array}$ & 0.0317 & $\begin{array}{c}-0.00714 \\
(-0.01,0.002)\end{array}$ & 0.1271 & $\begin{array}{c}-0.01052 \\
(-0.01,-0.001)\end{array}$ & 0.0246 & $\begin{array}{c}-0.6350 \\
(-1.11,-0.15)\end{array}$ & 0.0092 \\
\hline $\begin{array}{l}\text { Behvarz density per } 1000 \\
\text { individuals }\end{array}$ & $\begin{array}{c}0.00005 \\
(-0.01,0.01)\end{array}$ & 0.9932 & $\begin{array}{c}-0.00033 \\
(-0.008,0.007)\end{array}$ & 0.9364 & $\begin{array}{c}-0.00201 \\
(-0.009,0.005)\end{array}$ & 0.6052 & $\begin{array}{c}0.1313 \\
(0.22,0.24)\end{array}$ & 0.0203 \\
\hline Wealth index & $\begin{array}{c}-0.05012 \\
(-0.07,-0.02)\end{array}$ & $<0.0001$ & $\begin{array}{c}-0.05029 \\
(-0.06,-0.03)\end{array}$ & $<0.0001$ & $\begin{array}{c}-0.04813 \\
(-0.06,-0.03)\end{array}$ & $<.0001$ & $\begin{array}{c}-0.1019 \\
(-0.22,0.02)\end{array}$ & 0.1041 \\
\hline Years of schooling & $\begin{array}{c}0.004190 \\
(-0.02,0.02)\end{array}$ & 0.7402 & $\begin{array}{c}-0.00864 \\
(-0.02,0.01)\end{array}$ & 0.4243 & $\begin{array}{c}-0.00603 \\
(-0.02,0.01)\end{array}$ & 0.5402 & $\begin{array}{c}0.1636 \\
(0.01,0.3)\end{array}$ & 0.0284 \\
\hline Size of population & $\begin{array}{c}-0.09803 \\
(-0.13,-0.06)\end{array}$ & $<0.0001$ & $\begin{array}{c}-0.1063 \\
(-0.13,-0.07)\end{array}$ & $<.0001$ & $\begin{array}{c}-0.1175 \\
(-0.14,-0.08)\end{array}$ & $<0.0001$ & $\begin{array}{c}-0.1811 \\
(-0.35,-0.006)\end{array}$ & 0.0422 \\
\hline Mean age of population & $\begin{array}{c}-0.02812 \\
(-0.03,-0.01)\end{array}$ & $<0.0001$ & $\begin{array}{c}-0.03739 \\
(-0.04,-0.02)\end{array}$ & $<0.0001$ & $\begin{array}{c}-0.03714 \\
(-0.04,-0.02)\end{array}$ & $<0.0001$ & $\begin{array}{c}-0.09913 \\
(-0.15,-0.04)\end{array}$ & 0.0004 \\
\hline Urbanization rate & $\begin{array}{c}-0.03901 \\
(-0.18,0.10)\end{array}$ & 0.6036 & $\begin{array}{c}-0.09470 \\
(-0.22,0.03)\end{array}$ & 0.1468 & $\begin{array}{c}-0.1271 \\
(-0.24,-0.009)\end{array}$ & 0.0345 & $\begin{array}{c}0.2897 \\
(-0.39,0.97)\end{array}$ & 0.4091 \\
\hline Time effect & $\begin{array}{c}-0.04658 \\
(-0.05,-0.03)\end{array}$ & $<0.0001$ & $\begin{array}{c}-0.03880 \\
(-0.04,-0.03)\end{array}$ & $<0.0001$ & $\begin{array}{c}-0.03392 \\
(-0.03,-0.02)\end{array}$ & $<0.0001$ & $\begin{array}{c}-0.01895 \\
(-0.06,0.02)\end{array}$ & 0.4368 \\
\hline
\end{tabular}

$I M R=$ number of infant deaths per 1000 live births; $M M R=$ number of pregnancy-related maternal deaths per 100 ooo live births; NMR = number of neonatal deaths per 1000 live births; U5MR = number of under-5-year deaths per 1000 live births.

information at a national level (with comparable quality) limited the opportunity to evaluate the hypothesis that increased midwife density can reduce maternal and child mortality.

The Iranian health system stands 104th among 188 worldwide in the path to sustainable development, based on a report published by the Global Burden of Diseases 2015 SDG collaborators (2). That study showed that the Iranian health system had reached targets related to lowering MMR, U5MR and NMR, although it still had to tackle burdens caused by road injuries, unsafe sources of water, partner violence, and unacceptable sanitation and hygiene among people. Their estimate showed that $85.9 \%$ of the Iranian population is covered by interventions related to UHC, and efforts are needed to improve public access to quality essential health services. Moreover, with the ageing of populations, countries like the Islamic Republic of Iran are expected to experience an increasing burden due to NCDs $(20,21)$. The launching of the Family Physician and Social Protection Scheme has successfully contributed to reducing child and maternal mortality rates. However, with the transition in disease profiles, improvements in the Scheme are needed to provide patients with the care necessary for NCDs, and to decrease inequality in access to services.

\section{Acknowledgement}

The authors wish to thank the staff at the Non-Communicable Diseases Research Center (Tehran University of Medical Sciences).

Funding: This study was funded by a grant from Tehran University of Medical Sciences (grant number: 9111382016).

Competing interests: None declared. 


\section{Densité des ressources humaines pour la santé et son association avec la mortalité infanto-maternelle en République islamique d'Iran}

\section{Résumé}

Contexte: Le système de médecins de famille et de protection sociale pour les habitants des zones rurales iraniennes a été lancé en juin 2005 pour améliorer la densité des médecins. À notre connaissance, l'impact de ce système sur les indicateurs de santé liés à la mortalité n'a pas fait l'objet d'une étude exhaustive.

Objectifs : Étudier les effets de la densité de personnels de santé sur les taux de mortalité maternelle, néonatale, infantile et des enfants de moins de cinq ans dans les zones rurales de la République islamique d'Iran entre 2005 et 2011.

Méthodes: Nous avons construit des modèles de régression de Poisson à effets mixtes, intégrant des mesures de la mortalité en tant que variables de réponse, des densités de médecins et de behvarz (agents de santé communautaires) en tant que variables indépendantes, en utilisant des données de l'outil iranien Vital Horoscope, de l'enquête annuelle sur les revenus et les dépenses des ménages et du logiciel DTARH. Nous avons également inclus la taille de la population, l'âge des habitants, le taux d'urbanisation, les années de scolarité et l'indice de richesse dans chaque district, ainsi que l'effet du temps, en tant que covariables.

Résultats : La densité de médecins était fortement associée aux taux de mortalité de l'enfant (baisse de 1,5\%, 1,1 \% et 63,5\% de la mortalité maternelle, néonatale et des moins de cinq ans lors d'une augmentation d'une unité de la densité de médecins pour 1000 personnes). Dans le modèle établi pour le taux de mortalité infantile, la densité de médecins et les densités de behvarz n'étaient pas associées de manière significative à cette mesure.

Conclusions : L'amélioration de la répartition des médecins de famille est associée à une baisse de la mortalité infantile et maternelle. Les progrès en matière de densité de behvarz n'étaient pas associés à des baisses de ces taux, ce qui nécessite probablement une amélioration de l'accès à des services et installations de santé plus professionnels.

$$
\begin{aligned}
& \text { كثافة الموارد البشرية في ججال الصحة وما يرتبط بها من وفيات الأطفال والأمهات في جمهورية إيران الإسلامية } \\
& \text { زهرة مدادي، فرهاد بيشجار، عرفان قاسمي، علي رضا خاجاوي، سحر مقدم، فرشاد فرزادفار }
\end{aligned}
$$

الخلفية: بدأ تنفيذ برنامج طبيب الأسرة والحماية الاجتماعية لسكان الريف الإيرانيين في يونيو / حزير المايران 2005 لتحسين كثافة الأطباء. وعلى حد

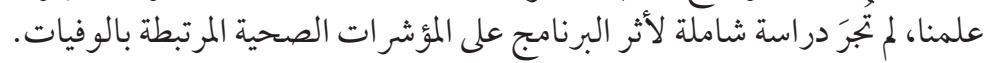

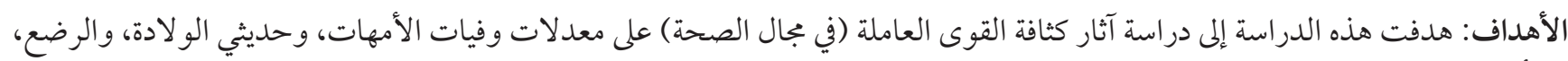

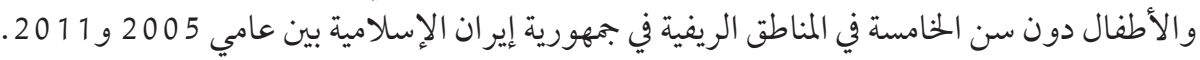

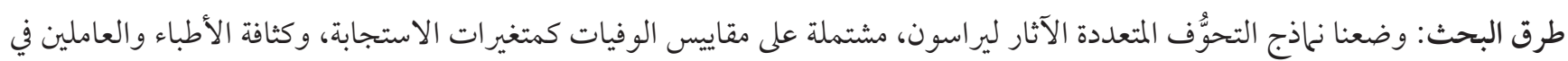

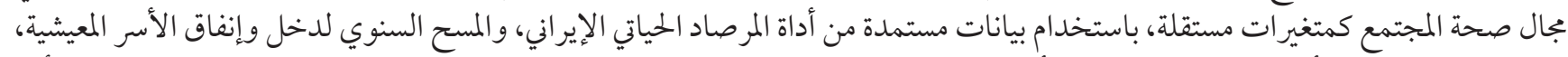

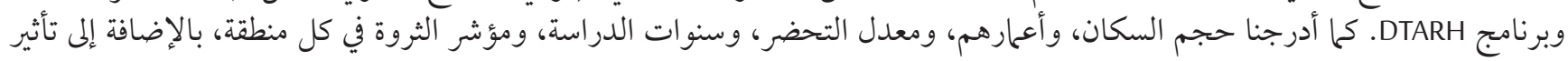
الوقت، كمتغيرات مشتركة.

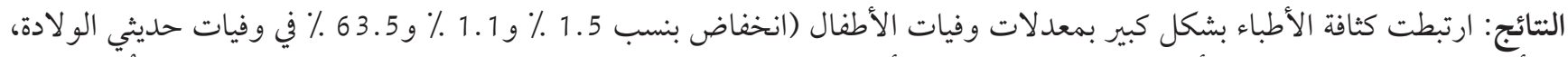

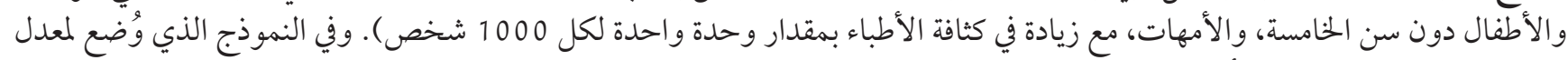

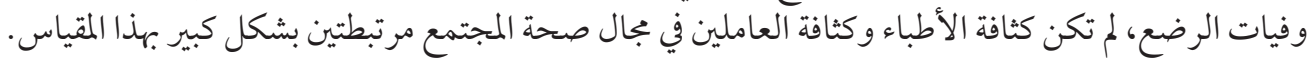

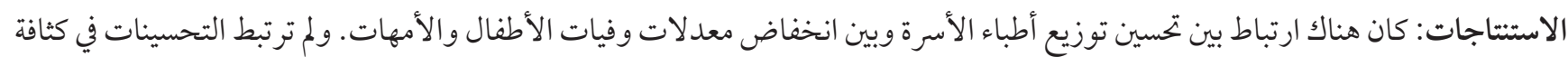

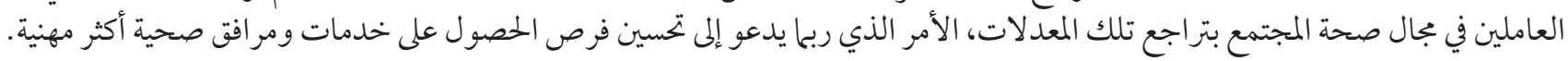




\section{References}

1. Lee BX, Kjaerulf F, Turner S, Cohen L, Donnelly PD, Muggah R, et al. Transforming our world: implementing the 2030 agenda through sustainable development goal indicators. J Public Health Policy. 2016 Sep;37(Suppl 1):13-31. http://dx.doi.org/10.1057/ S41271-016-0002-7 PMID:27638240

2. Measuring the health-related Sustainable Development Goals in 188 countries: a baseline analysis from the Global Burden of Disease Study 2015. Lancet. 2016 Oct 8;388(10053):1813-50. http://dx.doi.org/10.1016/So140-6736(16)31467-2 PMID:27665228

3. Universal health coverage (UHC) 2016. Geneva: World Health Organization; 2016 /.

4. Campbell J, Buchan J, Cometto G, David B, Dussault G, Fogstad H, et al. Human resources for health and universal health coverage: fostering equity and effective coverage. Bulletin of the World Health Organization. 2013 Nov 1;91(11):853-63. http://dx.doi. org/10.2471/BLT.13.118729 PMID:24347710

5. Chen L, Evans T, Anand S, Boufford JI, Brown H, Chowdhury M, et al. Human resources for health: overcoming the crisis. Lancet. 2004 Nov 27;364(9449):1984-90. http://dx.doi.org/10.1016/So140-6736(04)17482-5 PMID:15567015

6. Farzadfar F, Murray CJ, Gakidou E, Bossert T, Namdaritabar H, Alikhani S, et al. Effectiveness of diabetes and hypertension management by rural primary health-care workers (Behvarz workers) in Iran: a nationally representative observational study. Lancet. 2012 Jan 7;379(9810):47-54. http://dx.doi.org/10.1016/S0140-6736(11)61349-4 PMID:22169105

7. Robinson JJ, Wharrad H. The relationship between attendance at birth and maternal mortality rates: an exploration of United Nations' data sets including the ratios of physicians and nurses to population, GNP per capita and female literacy. J Adv Nurs. 2001 May;34(4):445-55. http://dx.doi.org/10.1046/j.1365-2648.2001.01773.x PMID:11380711

8. Takian A, Doshmangir L, Rashidian A. Implementing family physician programme in rural Iran: exploring the role of an existing primary health care network. Fam Pract. 2013 Oct;30(5):551-9. https://doi.org/10.1093/fampra/cmt025

9. Sousa A, Dal Poz MR, Boschi-Pinto C. Reducing inequities in neonatal mortality through adequate supply of health workers: evidence from newborn health in Brazil. PloS One. 2013 Sep 20;8(9):e74772. http://dx.doi.org/10.1371/journal.pone.0074772 PMID:24073222

10. Fernandes QF, Wagenaar BH, Anselmi L, Pfeiffer J, Gloyd S, Sherr K. Effects of health-system strengthening on under-5, infant, and neonatal mortality: 11-year provincial-level time-series analyses in Mozambique. Lancet Glob Health. 2014 Aug 1;2(8):e46877. https://doi.org/10.1016/S2214-109X(14)70276-1

11. Anand S, Barnighausen T. Human resources and health outcomes: cross-country econometric study. Lancet. 2004 Oct 30-Nov 4;364(9445):1603-9. http://dx.doi.org/10.1016/So140-6736(04)17313-3 PMID:15519630

12. GBD 2015 Child Mortality Collaborators. Global, regional, national, and selected subnational levels of stillbirths, neonatal, infant, and under-5 mortality, 1980-2015: a systematic analysis for the Global Burden of Disease Study 2015. Lancet. 2016 Oct 8;388(10053):1725-74. http://dx.doi.org/10.1016/So140-6736(16)31575-6 PMID:27733285

13. Rahbar M, Ahmadi M, Lornejad H, Habibelahi A, Sanaei-Shoar T, Mesdeaghinia A. Mortality causes in children 1-59 months in iran. Iran J Public Health. 2013 Jan 1;42(Suppl 1):93-7. PMID:23865024

14. Compaore GD, Sombie I, Ganaba R, Hounton S, Meda N, Brouwere VD, et al. Readiness of district and regional hospitals in Burkina Faso to provide caesarean section and blood transfusion services: a cross-sectional study. BMC Pregnancy Childbirth. 2014 May 2;14:158. http://dx.doi.org/10.1186/1471-2393-14-158 PMID:24886218

15. Pricilla RA, David KV, Rahman SPMF, Sankarapandian V, Kumar Y, Angeline N. Introduction of routine obstetric ultrasound in an urban health center: results and benefits. J Med Ultrasound. 2014 Dec;22(4):218-21. https://doi.org/10.1016/j.jmu.2014.06.006

16. Naderimagham S, Jamshidi H, Khajavi A, Pishgar F, Ardam A, Larijani B, et al. Impact of rural family physician program on child mortality rates in Iran: a time-series study. Popul Health Metrics. 2017;15:21. https://doi.org/10.1186/s12963-017-0138-0

17. Singh-Manoux A, Dugravot A, Smith GD, Subramanyam M, Subramanian SV. Adult education and child mortality in India: the influence of caste, household wealth, and urbanization. Epidemiology. 2008 Mar;19(2):294-301. http://dx.doi.org/10.1097/ EDE.obo13e3181632c75 PMID:18300716

18. Scott S, Chowdhury ME, Pambudi ES, Qomariyah SN, Ronsmans C. Maternal mortality, birth with a health professional and distance to obstetric care in Indonesia and Bangladesh. Tropical medicine \& international health : Trop Med Int Health. 2013 Oct;18(10):1193-201. http://dx.doi.org/10.1111/tmi.12175 PMID:23980717

19. Vedam S, Stoll K, MacDorman M, Declercq E, Cramer R, Cheyney M, et al. Mapping integration of midwives across the United States: Impact on access, equity, and outcomes. PloS One. 2018 Feb 21;13(2):e0192523. http://dx.doi.org/10.1371/journal.pone.0192523 PMID:29466389

20. Mokdad AH. Burden of cardiovascular diseases in the Eastern Mediterranean Region, 1990-2015: findings from the Global Burden of Disease 2015 study. Int J Public Health. 2017 May;63(Suppl 1):137-49. http://dx.doi.og/10.1007/s00038-017-1012-3 PMID:28776245

21. GBD 2015 Eastern Mediterranean Region Cancer Collaborators. Burden of cancer in the Eastern Mediterranean Region, 2005-2015: findings from the Global Burden of Disease 2015 Study. Int J Public Health. 2017 May;63(Suppl 1):151-64. http://dx.doi. org/10.1007/s00038-017-0999-9 PMID:28776254 